\title{
Screening, isolation and identification of microorganisms from petrochemical contaminated environment
}

\section{Solomon Oluwole Oladeji ${ }^{1}$ and Kehinde Abraham Odelade ${ }^{2}$}

${ }^{1}$ Department of Pure and Applied Chemistry, Ladoke Akintola University of Technology, P.M.B 4000, Ogbomoso, Nigeria.Email: oladeji_oluwole@yahoo.com. 2Department of Pure and Applied Biology, Ladoke Akintola University of Technology, P.M.B 4000, Ogbomoso, Nigeria.

\begin{abstract}
Soil is comprised of minerals, soil organic matter, water and air. The composition and proportion of these components greatly influence soil physical properties like structure and porosity. Soil bacteria and fungi play pivotal roles in various biogeochemical cycles and are responsible for the cycling of organic compounds. The view on the microbiological safety of drinking water is changing. The demand for the total absence of any pathogenic organism is no longer significant in light of the new pathogens, some of which are capable of growing in drinking water systems. This is mainly due to many pollutants that are present at much higher concentrations in groundwater than they are in most contaminated surface supplies. In order to determine the microbes, soil and water samples were collected from petrochemical industry, Eleme, Port-Harcourt, Rivers State, Nigeria, for microbiological analysis. This was carried out by the isolation, assessment and characterization of the isolated organisms. The highest bacterial counts was determined in soil sample 1 (SS1) and water sample 4 (WS4) with microbial loads of $1.48 \times 10^{6} \mathrm{cfu} / \mathrm{mL}$ and $9.40 \times 10^{5}$ $\mathrm{cfu} / \mathrm{mL}$ and the lowest count was found in soil sample 2 (SS2) and water sample 2 (WS2) with microbial load $2.90 \times 10^{5} \mathrm{cfu} / \mathrm{mL}$ and $3.67 \times 10^{4} \mathrm{cfu} / \mathrm{mL}$. The highest fungal counts was determined in soil sample 2 (SS2) and water sample1 (WS1) with microbial loads of $1.76 \times 10^{6} \mathrm{cfu} / \mathrm{mL}$ and $2.17 \times 10^{6} \mathrm{cfu} / \mathrm{mL}$ and the least colonies was in soil sample 1 (SS1) and water sample 2 (WS2) with microbial counts of $1.75 \times 10^{5} \mathrm{cfu} / \mathrm{mL}$ and $4.30 \times 10^{4} \mathrm{cfu} / \mathrm{mL}$. The results present that the presence of these microbes can be linked to the prehistory of the effects or contamination of surface and underground water in this region and could leads to water-borne diseases.
\end{abstract}

Keywords: Organic matter; Biogeochemical cycles; Pathogenic organisms; Pollutants, Microbes.

\section{Introduction}

Soil is a natural body consisting of layers (horizons) of mineral constituents, each with different proportions and has some distinctive features which differentiate them from their parent materials due to the interaction between the lithosphere, hydrosphere and the biosphere It comprises of particles of broken rock that have been altered by chemical and environmental processes that include 
weathering and erosion (Sabata and Nayar, 1995). Some of these are morphological, physical, chemical, and mineralogical characteristics (Bhatt et al., 1999). The soil contains about $10 \%$ of organic matter, this have a tremendous effect on soil chemical and physical properties. It consists of organic matter such as carbon, oxygen, hydrogen, nitrogen and smaller quantities of sulphur and other elements. The impact of soil on agricultural productivity and sustainability can be determined by analyzing the physical, chemical and biological parameters of the soil (Mohan et al., 2007).

In recent times, due to technological advancements, human activities and increasing in population density, the view on the safety of drinking water is not predictable. Due to the health effects of these waters, the demand for the total absence of any pathogenic organisms is no longer significant in light of the new pathogens, some of which are capable of growing in drinking water systems. According to the new European Union Council Directive 98/83/EC, water for human consumption must be free from any microorganisms and parasites and from any harmful substances or pollutants which concentrations either either low or high can lead or constitute a potential danger to human health (European Union Council, 1998). To combat this, this agency, that is, Environmental Protection Agency used a microbial risk assessment approach. It has been defined that an annual risk of 1.034 (one infection per 10,000 consumers per year) should be acceptable for diseases acquired through potable or drinking water. The value $\left(4 \times 10^{-3}\right)$ has close proximity to the annual risk of infection from waterborne disease outbreaks in the United States (USEPA, 2006).

Microbiological risk assessment is a major tool for decision making in the regulatory area. The problem is, however, that the key data to perform this assessment are mostly missing. Few epidemiological studies associating the incidence of disease to the pathogen densities have been reported. Several outcomes, from asymptomatic infection to death, are possible through exposure to microbes. The issue of dose-response relationships is alarming. The relationship is applicable to few pathogens when the dosage concentration is low most especially for viruses and protozoan (Kolade, 1982). The calculated tolerable concentrations are also low and monitoring of these pathogens in drinking water becomes impracticable (Mark et al., 2002).

Pathogenic bacteria can be transmitted through water; these are known as water-borne bacteria. The most important pathogenic bacteria transmitted by the water route is Salmonella typhi, this causes typhoid fever and Vibrio cholerae, the organism causing cholera (Arvnabh et al., 2001). Soil bacteria and fungi play pivotal roles in various biogeochemical cycles (BGC) (Ali, 1991; Roy and Kumar, 2002; Hemant et al., 2012) and are responsible for the cycling of organic compounds. Soil microorganisms also 10 influence above-ground ecosystems by contributing to plant nutrition (Tebutt, 1983), plant health (Kumar, 1997), soil structure and soil fertility. Our knowledge of soil microbial diversity is limited in part by our inability to study soil microorganisms (Bassey, 2008). They also carried out research and discovered that in 1 $\mathrm{g}$ of the soil sample, there are 4000 different bacterial "genomic units" based on DNA-DNA re-association. It has also been estimated that about 5000 bacterial species have been described (Rahda et al., 2007). Approximately $1 \%$ of the soil bacterial population can be cultured by standard laboratory practices.

In the attempt to analyse the microbes present in soil and water, soil and water samples were collected from a petrochemical contaminated environment. The research project was conducted with following objectives, isolation of different bacteria found in the soil and water samples collected, assessment of microbial loads in the soil and water samples collected and characterization of the isolated organisms. 


\section{Materials and methods}

\section{Collection of samples}

Different soil and water samples were collected from petrochemical industry, Eleme, Port-Harcourt, Rivers state, Nigeria for microbiological analysis. These samples were transferred into a clean sample bottles and stored at $4{ }^{\circ} \mathrm{C}$.

Preparation of potato dextrose agar (PDA) and nutrient agar (NA)

About $39 \mathrm{~g}$ of potato dextrose agar (PDA) was accurately weighed and dissolved in $1000 \mathrm{~mL}$ of deionized water. About $28 \mathrm{~g}$ of nutrient agar was accurately weighed and dissolved in $1000 \mathrm{~mL}$ of distilled water. To prevent bacterial and fungal contaminations, $2 \mathrm{~mL}$ of tetracycline and nystatin was added. The media were prepared, mixed thoroughly and sterilized by autoclaving at $121^{\circ} \mathrm{C}$ for $15 \mathrm{~min}$.

\section{Isolation of fungi and bacteria from the collected soil and leaf samples}

The microorganisms, fungi and bacteria were isolated by serial dilution plate method. About $1 \mathrm{~g}$ of the sample was accurately weighed and suspended in $9 \mathrm{~mL}$ of double distilled water to make microbial suspensions $\left(10^{-1}\right.$ to $\left.10^{-3}\right)$. Dilutions of $10^{-2}$ and $10^{-3}$ were used to isolate both fungi and bacteria. $1 \mathrm{~mL}$ of microbial suspension of each concentration were added to sterile Petri dishes (triplicate of each dilution) containing $15 \mathrm{~mL}$ of sterile PDA and NA for bacteria and fungi isolation and incubated for four days at $4{ }^{\circ} \mathrm{C}$ (bacterial) and $37^{\circ} \mathrm{C}$ for $24 \mathrm{~h}$ (fungal). The growth of the organisms were counted using colony counter and the microbial loads were calculated in CFU/mL although no growth was observed on fungal plates after 4 days of incubation. Therefore, only bacterial colonies were sub-cultured by streaking on new solidified nutrient agar plates to obtain pure cultures. After pure isolates have been obtained, they were stored in slant bottles for characterizations.

\section{Characterization of the bacterial isolates \\ Colonial characteristics of the} bacterial isolates were determined using parameters such as size, elevation, pigment, surface, opacity, edge and shape. Cellular characteristics of the isolates were determined through the following experiments:

\section{Gram's staining}

Smear of each bacterial isolate was prepared on a clean slide. In preparing the smear a drop of sterile distilled water was placed in the middle of the slide. A sterilized inoculating needle was used to pick from the bacterial colony and rubbed on the slide containing a drop of sterile distilled water. The bacterial cells were spread into a thin smear, air dried and heat fixed (Fawole and Oso, 2001). The heat fix smear was stained with crystal violet for 1 to 2 min after which the stain was poured off. The smear was rinsed off with Gram's iodine and the iodine was allowed to react for 1 minute with the smear. The slide was then washed with $95 \%$ alcohol until the violet was seen to stop running from the slide. The slide was rinsed with gentle running tap water and counterstained with safranin for 1 to $2 \mathrm{~min}$. The slide was rinsed with water, blotted dry and examined under microscope with oil immersion. Gram positive cells appeared purple while gram negative cells appeared pink.

\section{Motility test}

The hanging-drop method was used to determine the motility of the bacterial isolates according to the method of Olutiola et al. (1991) and was examined immediately under the X40 objective lens.

\section{Spore staining}

Heat-fixed smear of each isolate was prepared in a slide. Malachite green solution was added to the smear and steamed for 10 minutes. The stain was not allowed to dry out. The stain was then 
washed off with cold water. The smear was counterstained with safranin solution for 15 s. It was wash with water, blotted dry and examined under the microscope with the oil-immersion objective (Olutiola el al., 1991). Spores appeared green and bacterial cells appeared red.

\section{Capsule staining}

Air-dried smear of each isolate was prepared and fixed on a slide. Crystal violet was applied on the slide for $2 \mathrm{~min}$ and the slide was then steamed for $40 \mathrm{~min}$. The crystal violet was rinsed off with copper sulphate solution. Each slide was blotted carefully, dried in the air and examined under the microscope using oil immersion lens. Bacterial cells appeared deep violet while the capsules appeared pale violet.

\section{Catalase test}

The catalase test was carried out according to the method of Fawole and Oso ( 2001) using a thick emulsion of each test organism and several drops of 3\% hydrogen peroxide were added on each of the slides.

\section{Oxidase test}

A filter paper was soaked in $1 \%$ sodium oxalate solution. A portion of each bacterial colony was picked and rubbed on the filter paper. A blue colour change within $10 \mathrm{~s}$ indicated the production of the enzyme oxidase.

\section{Methyl red test}

Accurately $10 \mathrm{~mL}$ of glucose phosphate broth was prepared into different test tubes. The test tubes were then inoculated with different bacterial isolates. The test tubes were incubated for 3 days at $37{ }^{0} \mathrm{C}$. After 3 days, 5 drops of methyl red indicator was added to $5 \mathrm{~mL}$ of each cultured broth. Acid production was indicated by a yellow colouration.

\section{Indole test}

$1 \%$ tryptone broth was prepared in different test tubes. The test tubes were inoculated with each bacterial isolate. The tubes were then incubated for $48 \mathrm{~h}$ at $35^{\circ} \mathrm{C}$. After incubation, $2 \mathrm{~mL}$ of chloroform was added to each broth culture and was shook gently. $2 \mathrm{~mL}$ of Kovac's reagent was added to the broth culture and shook gently. The tubes were allowed to stand for $20 \mathrm{~min}$ in order to permit the reagent to rise to the top. A red colour at the reagent layer indicated indole production.

\section{Starch hydrolysis}

The starch hydrolysis was carried out according to the method of Fawole and Oso (2001).

\section{Citrate utilization}

Citrate agar plates were inoculated with the bacterial isolates using streaking method. The plates were incubated at $37^{\circ} \mathrm{C}$ for $24 \mathrm{~h}$. Colour change from green to blue on the plates indicated citrate utilization by the test organisms.

\section{Sugar fermentation}

The sugar tested for fermentation included fructose, maltose, lactose, sucrose and glucose. Nutrient broth containing $0.5 \%$ of each of the sugar was prepared. Two drops of $0.01 \%$ phenol red indicator was added to each of the broth media. $10 \mathrm{~mL}$ of each of the broth media was dispensed into test tubes containing inverted Durham tubes. The media setup was sterilized by steaming for $30 \mathrm{~min}$ on three successive days.

Each indicator-sugar-broth was inoculated with a loopful of each of the bacterial isolates. One test tube of each medium was left uninoculated as a control. The test tubes were incubated at $35^{\circ} \mathrm{C}$ for 4 days. Growth occurred in the inoculated tubes and absent in uninoculated tubes. The change in colour from red to yellow indicated acid production and the presence of air space in the Durham tubes.

\section{Oxygen relationship \\ McCartney bottles containing} sterile nutrient agar were used. The bottles were inoculated while at semi-solid state with each of the bacterial isolate using stabling technique. The agar in the McCartney bottles were allowed to solidify and incubated at $37^{\circ} \mathrm{C}$ for $48 \mathrm{~h}$. Anaerobes grew at the bottom of the bottles, aerobes grew on the surface and facultative 
anaerobes grew from the bottom through the bottles to the top (Fawole and Oso, 2001). The fungal isolates were identified with the help of Bunett et al. (1998) and Mark et al. (2002).

\section{Results and discussion}

The isolation of microorganisms of the collected different soil and water samples from petrochemical industry, Eleme, Port-Harcourt, Rivers State, Nigeria was carried out using nutrient agar and potato dextrose agar as media. Many organisms were isolated from both soil and water samples in Table 1 . The highest bacterial counts was determined in soil sample 1 (SS1) and water sample 4 (WS4) with microbial loads of $1.48 \times 10^{6} \mathrm{cfu} / \mathrm{mL}$ and $9.40 \times 10^{5} \mathrm{cfu} / \mathrm{mL}$, respectively, followed by soil sample 3 (SS3) and water sample 1 (WS1) with microbial count of $6.70 \times 10^{5} \mathrm{cfu} / \mathrm{mL}$ and $3.10 \times 10^{5} \mathrm{cfu} / \mathrm{mL}$, respectively, then soil sample 4 (WS4) and water sample 5 (WS5) with microbial loads of $3.90 \times 10^{5} \mathrm{cfu} / \mathrm{mL}$ and $2.80 \times 10^{5} \mathrm{cfu} / \mathrm{mL}$, respectively. The lowest fungal count was found in soil sample 2 (SS2) and water sample 2 (WS2) with microbial load $2.90 \times 10^{5} \mathrm{cfu} / \mathrm{mL}$ and $3.67 \times 10^{4} \mathrm{cfu} / \mathrm{mL}$ and the least bacterial colonies was in soil sample 5 (WS5).

Also, from Table 1, a quite a number of organisms were isolated from both soil and water samples for fungi. The highest fungal counts was found in soil sample 2 (SS2) and water sample 1 (WS1) with microbial loads of $1.76 \times 10^{6} \mathrm{cfu} / \mathrm{mL}$ and $2.17 \times 10^{6} \mathrm{cfu} / \mathrm{mL}$, respectively, followed by soil sample 4 (SS4) and water sample5 (WS5) with microbial count of $4.50 \times 10^{5} \mathrm{cfu} / \mathrm{mL}$ and $5.60 \times 10^{5} \mathrm{cfu} / \mathrm{mL}$, respectively. The least bacterial colonies was in soil sample 1 (SS1) and water sample 2 (WS2) with microbial counts of $1.75 \times 10^{5} \mathrm{cfu} / \mathrm{mL}$ and $4.30 \times 10^{4} \mathrm{cfu} / \mathrm{mL}$, respectively.

There are a quite numbers of microorganism, bacteria and fungi isolated from the samples (soil and water) collected from the petrochemical industry, Eleme, Port-Harcourt, Rivers State, Nigeria. These organisms were shown in Table 2.

Table 1. Results of microbial counts of the bacterial and E. coli form colonies.

\begin{tabular}{|l|c|c|c|}
\hline Samples & DF & NA (cfu/mL) & PDA (cfu/mL) \\
\hline SS1 & $10^{-2}$ & $2.28 \times 10^{5}$ & $2.14 \times 10^{4}$ \\
& $10^{-3}$ & $1.48 \times 10^{6}$ & $1.75 \times 10^{5}$ \\
\hline SS2 & $10^{-2}$ & $4.10 \times 10^{3}$ & $1.70 \times 10^{4}$ \\
& $10^{-3}$ & $2.90 \times 10^{5}$ & $1.76 \times 10^{6}$ \\
\hline SS3 & $10^{-2}$ & $1.54 \times 10^{5}$ & $4.0 \times 10^{4}$ \\
& $10^{-3}$ & $6.70 \times 10^{5}$ & $3.3 \times 10^{5}$ \\
\hline SS4 & $10^{-2}$ & $9.80 \times 10^{3}$ & $9.30 \times 10^{3}$ \\
& $10^{-3}$ & $3.90 \times 10^{5}$ & $4.50 \times 10^{5}$ \\
\hline SS5 & $10^{-2}$ & $3.23 \times 10^{4}$ & $2.70 \times 10^{4}$ \\
& $10^{-3}$ & $2.49 \times 10^{5}$ & $2.0 \times 10^{5}$ \\
\hline WS1 & $10^{-2}$ & $2.63 \times 10^{5}$ & $3.50 \times 10^{5}$ \\
& $10^{-3}$ & $3.10 \times 10^{5}$ & $2.17 \times 10^{6}$ \\
\hline WS2 & $10^{-2}$ & $1.09 \times 10^{4}$ & $3.1 \times 10^{4}$ \\
& $10^{-3}$ & $3.67 \times 10^{4}$ & $4.3 \times 10^{4}$ \\
\hline WS3 & $10^{-2}$ & $1.10 \times 10^{4}$ & $4.69 \times 10^{4}$ \\
& $10^{-3}$ & $2.84 \times 10^{4}$ & $6.78 \times 10^{5}$ \\
\hline WS4 & $10^{-2}$ & $1.72 \times 10^{5}$ & $4.0 \times 10^{4}$ \\
\hline WS5 & $10^{-3}$ & $9.40 \times 10^{5}$ & $1.80 \times 10^{3}$ \\
& $10^{-2}$ & $4.00 \times 10^{3}$ & $5.60 \times 10^{5}$ \\
\hline
\end{tabular}


Table 2. Bacteria and fungi probable organisms isolated from respective soil and water sample.

\begin{tabular}{|c|c|c|}
\hline Sample & Bacteria & Fungi \\
\hline SS1 & $\begin{array}{l}\text { Pseudomonas aeruginosa, Bacillus cereus, } \\
\text { Acetobacter spp }\end{array}$ & Aspergillus niger, Penicillium chrysogenum \\
\hline SS2 & $\begin{array}{l}\text { Lactobacillus spp, Pseudomonas putida, } \\
\text { Nictrobacter spp, Staphylococcus aureus }\end{array}$ & Aspergillus niger, Aspergillus flavus \\
\hline SS3 & $\begin{array}{l}\text { Staphylococcus aureus, Acetobacter spp, } \\
\text { Nictrobacter spp }\end{array}$ & Aspergillus vasisolor, Aspergillus flavus \\
\hline SS4 & $\begin{array}{l}\text { Bacillus cereus, Bacillus substilis, } \\
\text { Pseudomonas aeruginosa }\end{array}$ & enum \\
\hline SS5 & Nitrobacter spp, Staphylococcus aureus & Aspergillus niger, Aspergillus flavus \\
\hline WS1 & $\begin{array}{l}\text { Clostridium spp, Staphylococcus aureus, } \\
\text { Pseudomonas aeruginosa }\end{array}$ & Aspergillus vasisolor, Aspergillus niger \\
\hline WS2 & $\begin{array}{l}\text { E. coli, Staphylococcus aureus, Lactobacilli } \\
\text { spp }\end{array}$ & Aspergillus niger, Aspergillus flavus \\
\hline WS3 & $\begin{array}{l}\text { Staphylococcus aureus, Pseudomonas } \\
\text { aeruginosa, Lactobacilli spp }\end{array}$ & Aspergillus niger, Aspergillus flavus \\
\hline WS4 & $\begin{array}{l}\text { Pseudomonas putida, Clostridium spp, } \\
\text { Staphylococcus aureus }\end{array}$ & Aspergillus flavus, Aspergillus vasisdor \\
\hline WS5 & $\begin{array}{l}\text { Pseudomonas putida, E. coli, Pseudomonas } \\
\text { aeruginosa }\end{array}$ & Aspergillus niger, Penicillium chrysogenum \\
\hline
\end{tabular}

The results obtained showed that there will be highest microbial activities of bacteria in the soil and water samples collected form soil sample 1 (SS1) and water sample 4 (WS4) because they had the highest microbial counts while the least microbial activities will be in the soil and water samples collected from soil sample 5 (SS5) and water sample 3 (WS3) because they had the least microbial loads. Also, this means that there will the highest microbial activities of fungi in the soil and water samples collected from soil sample 2 and water sample 1 because they had the highest microbial counts while the least microbial activities will be in the soil and water samples collected from soil sample 1 and water sample 2 because they had the least microbial loads. Escherichia coli are the most widely adopted indicator of faecal pollution and they can also be isolated and identified simply, with their numbers usually being given in the form of faecal coliforms $/ 100 \mathrm{~mL}$ of wastewater (Parihar et al., 2003). Outbreaks of these diseases can occur as a result of, drinking water from wells polluted by a combination of different wastewater microorganism species, eating contaminated fish, or indulging in recreational activities in polluted water bodies containing water borne pathogen. $E$. coli cause urinary tract infection and diarrheal (Hemant et al., 2012).

A large variety of bacteria, fungi, viral and protozoan pathogens are capable of initiating waterborne infections. Some are primarily the enteric bacterial pathogens including classic agents such as Vibrio cholerae, Salmonella spp., Shigella spp., and newly recognized pathogens from faecal sources like Campylobacter jejuni and enterohemorrhagic E. coli. The survival potential of these bacteria increases in biofilms and due to their stages as VBNC (viable but non-culturable) cells. Several new bacterial pathogens such as Legionella spp., Aeromonas spp, Pseudomonas aeruginosa and Mycobacterium avium have a natural reservoir in the aquatic environment and soil. These organisms are introduced from the surface water into the drinking water system usually in low numbers. They may survive and grow within the distribution system biofilm (Wilson et al., 1983). The presence of bacteria is of great importance in the water industry with regards to water-borne diseases. Some of such diseases are 
dysentery, typhoid fever, paratyphoid fever, cholera, infantile paralysis, poliomyelitis, infectious hepatitis, guinea worm, amoebic dysentery, amongst others. Transmission of the causative micro-pathogenic organism is through direct or indirect contamination of water source by human excreta most especially the microorganisms present in the soil and water (Edema et al., 2001). Since it is extremely difficult to isolate and identify different forms of pathogens, the microorganisms which are of significance to water quality are those of enteric pathogenic origin.

Water-borne diseases are diseases contracted through the ingestion of contaminated water. Table 3 present some of such diseases and their causative agents (Mills, 2000).

Table 3. Some water-borne diseases and their causative agents.

\begin{tabular}{|l|c|}
\hline Disease & Causative organism \\
\hline Bacterial dysentery & Shigella dysentera \\
\hline Typhoid fever & Salmonella typhii \\
\hline Para typhoid fever & Salmonella paratyphii \\
\hline Cholera & Vibrio cholera \\
\hline Amoebic dysentery & Entamoeba histolytic \\
\hline Infantile paralysis (Poliomyelitis) & Poliomyelitis virus \\
\hline Infectious hepatitis & Hepatitis virus \\
\hline Guinea worm & Dracunculus mendenensis \\
\hline
\end{tabular}

\section{Conclusion}

Due to the long time the indigenous bacteria have had to degrade the organic matter originally present, subsurface environments contain little organic matter. Furthermore, when percolating through the porous media, water containing organic matter encounters attached bacteria which remove most of this organic matter. The microbial studies can be utilized for the prevention of any pathogenic diseases caused by the microbes found in soil and water. Regular check up of the aquatic life can help in maintaining ecological balance.

\section{Acknowledgements}

The authors want to appreciate the efforts of Doctor M. A. Ogundiran of the Department of Pure and Applied Biology, LAUTECH, Ogbomoso, Nigeria for his contributions during the course of the study.

\section{Conflict of interest}

The authors declare that they have no competing interests.

\section{References}

Ali, J. An assessment of the water quality of Ogunpa River Ibadan, Nigeria. Ibadan, Nigeria: University of Ibadan, 1991. (M.Sc. Dissertation).

APHA - American Public Health Association. Standard methods for the examination of water and wastewater. 18 ed. Washington, D. C.: Office American Public Health Association, 1992.

Arvnabh, M.; Vasishta, D.; Bhatt, N. S.; Pinal, S.; Kirit, P.; Chaitanya, P. Comparative study of physico-chemical and microbial parameters on lotic and 49 ground-waters in selected outlying areas of Central Gujarat. Journal of Chemical and Pharmaceutical Research, v. 2, no. 4, p. 174-177, 2010.

Bassey, E. E. Influence of maternal inheritance on genetic expression of yield and yield related traits in okra (Abelmoschcus esculentus (L.) Moench) in the humid tropical environment of Uyo, Southeastern Nigeria. In: Clark, E. V. (Ed.). Proceedings of African Regional 
Conference on Sustainable Development held in Uyo. Akwa Ibom State, 2008. v. 2, p. 50-58.

Bhatt, L. R.; Lacoul, H. D.; Lekhak, H.; Jha, P. K. Physicochemical characteristics and phytoplankton of Taudaha Lake, Kathmandu. Pollution Research, v. 18, no. 4, p. 353-358, 1999.

Burnett, R. T.; Cakmak, S.; Brook, J. R. The effect of the urban ambient air pollution mix on daily mortality rates in 11 Canadian cities. Canadian Journal of Public Health, v. 89, p. 152-156, 1998.

Edema, M. O.; Omemu, A. M.; Fapetu, O. M. Microbiology and physicochemical analysis of different sources of drinking water in Abeokuta, Nigeria. Nigerian Journal of Microbiology, v. 15, no. 1, p. 57-61, 2001.

European Union Council. Directive No. 98/44/EC of the European Parliament and of the Council of 6 July 1998, on the legal production of biotechnological inventions, 1998.

Fawole, M. O.; Oso, B. A. Laboratory Manual of Microbiology. Rev. ed. Ibadan: Spectrum Books, 2001.

Hemant, P.; Deepak, P.; Limaye, S. N. Studies on the physico-chemical status of two water bodies at Sagar City under anthropogenic influences. Advances in Applied Science Research, v. 3, no. 1, p. 31-44, 2012.

Kolade, O. A. Shallow wells as supplementary sources of water in Nasarawa, Gwon, Jos. Jos, Nigeria: Department of Geography and Planning, University of Jos, 1982. (M. Sc. Thesis).

Kumar, N. A. View on freshwater environment. Ecological Environmental and Conservation, v. 3, no. 3/4, 1997.

Mark, W. R.; Ximing, C.; Sarah, A. C. World water and food to 2025; dealing with security. Washington, D. C.: International Food Policy Research Institute, 2002.
Mills, C. W. The sociological imagination. Oxford: Oxford University Press, 2000.

Mohan, D.; Gaur, A.; Chodhary, D. Study of limnology and microbiology of Naya Talab, Jodhpur, Rajasthan. Proceeding National Symposium on Limnology, 2007. p. 64-68.

Olutiola, P. O.; Famurewa, O.; Sontang, H. G. An introduction to general microbiology: a practical approach. Geneva, Switzerland: Ca. Heidelberg verlagsanstaltund Dreuckerei GMbh., Heidelberg, Germany. 1991.

Parihar, V. L.; Sharma, M. S.; Sharma, L. L. Utility of bacteriological parameters for assessing best use and trophic status of seasonal water: a case study from Udaipur, Rjasthan. Pollution Research, v. 22, no. 2, p. 163-167, 2003.

Radha, K. R.; Dharmaraj, K.; Ranjitha, K. A comparative study on the physicochemical and bacterial analysis of drinking, bore well and sewage water in the three different places of Sivakasi. Journal of Environmental Biology, v. 28, no. 1, p. 105-108, 2007.

Roy, Y.; Kumar, R. A. A study of water quality of the rivers of Ranchi District. Industrial Journal of Environmental Protection, v. 21, no. 5, p. 398-402, 2002.

Sabata, B. C.; Nayar, M. P. River pollution in India: a case study of Ganga River. New Delhi: APH Publishing, 1995.

Tebutt, T. H. Y. Principles of quality control. Pergamon, England, 1983.

USEPA. Pesticides Industry Sales and Usage. Biological and Economic Analysis Divison. Office of Chemical Safety and Pollution Prevention. Washinghton, D.C: USEPA, 2006. Wilson, H. R.; McFarlane, D. K.; Phillips, G. C. Spatial frequency tuning of orientation selective units estimated by oblique masking. Vision Res., v. 23, p. 873-882, 1983. 